\title{
Development of Thematic Assessment Based on Interactive Game in Elementary School
}

\author{
Sri Utaminingsih ${ }^{1}, \mathrm{Su} \mathrm{ad}^{2}$, Fitrotun Nikmah ${ }^{3}$ \\ \{sri.utaminingsih@umk.ac.id ${ }^{1}$, Suad@umk.ac.id ${ }^{2}$, nikmah.fitri@gmail.com³\} \\ 1,2,3 Faculty of Teaching and Education, Universitas Muria Kudus \\ Gondang Manis PO. BOX 53 Bae, Kudus, Central Java, Indonesia \\ Phone (+62291) 438229, Fax (+62291)437198
}

\begin{abstract}
In carrying out the assessment, the teacher is important to create fun situation and conducive. The purpose of this research is knowing development and effectiveness of thematic assessment based on the interactive game of snake and ladder in class 3 theme 1 elementary school. The research method has been used is research and development (R\&D) the Borg and Gall model. Validity data is obtained through observation, interviews and questionnaires which has been given to experts, and teachers as users. The product is validated and tested to understand level of validity qualitatively and quantitatively through credibility testing, validity testing, reliability testing and test item analysis. To understand the effectiveness level of data, product has been analyzed by $t$-test. The resultshave been obtained: strengths, limits and level of effectiveness of the development of interactive game-based thematic assessment products which can be used to measure the level of knowledge, skill and attitude of elementary school students
\end{abstract}

Keywords: Thematic assessment development, Game-based assessment, Interactive Games

\section{Introduction}

Assessment becomes a very important component in the administration of education. The quality of learning and the quality of the assessment system are two interrelated components. A good learning system will produce good quality of learning, while the quality of learning can be seen from the result of the assessment. As revealed by Rasyid (2009:6), effort to improve the quality of education can be achieved by improving the quality of learning and the quality of assessment system.

It's explained by Permendikbud Number 23 of 2016, as a reference for curriculum learning assessment 2013, that Assessment is the process of collection and processing information to measure the achievement of student learning outcomes. Assessment of learning outcomes by teacher aims to monitor and evaluate the process, progress of learning, and improvement of student linierly.

Based on the result of observation, researcher has found some problems generally, about the assessment of studying in elementay schools. These are assessment instruments to measure student's learning result still less innovation and interesting. The application of learning outcomes is less successful. This happens because the the teacher are more priorityto the learning process only

Therefore, it's needed a creativity to develop assessmentsinstrumentinelementary school and accordance to the competencywhich has been taught, so the teacher can improve the 
quality of learning. As expressed by Rosyid (2009: 7), a good assessment system will encourage tecaherto determine good learning strategy and it can motivate students to learn better.

Assessment of study result neither formal nor informal should be held in a fun atmosphere. So, students can show what they are understood and can be done because it is done without fear, anxiety and stress (Uno, 2012: 35). The psychological of people to be tested includes students, of course they have a different feeling of anxiety. If the level of anxiety in students is high when tested, they will get an assessment result that tends to be lower than the real ability (Rosyid, 2009: 10).

So the mood of student can give influence to results of the assessment process. anxious and bored will influence the assessment. A condition which support, fun and unworried can make students express their ability easily and maximally.one of the solution which has been offered to minimize the problem is creating a fun atmosphere during the assessment.

Kusuma hassaid (2018: 26), that teacher can innovate to determinetechnique and method assessment, one of which is game-based assessment. We need to remember that students of elementary school who are in the 7-12 years age very happy with the game especially the lowwer class level, they are $1^{\text {st }}$ grade to Class $3^{\text {rd }}$ grade. Suyanto said $(2005: 114)$, that in essence all children like playing, only children who are not feeling well do not like to play. Because the game is an activity which has a low level of difficulty but has a high level of entertainment (Kusuma, 2018: 26)

Playing is an activity that is very liked by children at elementary school age. So, the teacher can use his enjoyment of games to improve the quality of children's learning. When playing, children's mental condition tends to be stable and vibrant so that conducive situations and this condition is beneficial for students to learn easilier. (Kusuma; 2017: 898)

According to Latuheru (in Yuliatun; 2014: 31), gameis used in learning can provide cognitive and creative benefits for students because it is able to provide a fun, relaxed atmosphere, but always conducive. The partof students will give a positive response to the game as reward to bored situation in the learning process.

The development of thematic assessment based on interactive games in the form of snake and ladder games in elementary schools can be used as one of the solution to create varied, innovative, creative, interesting assessment instruments and create a fun atmosphere for assessment

\section{Literature Review}

Thematic Assessment. When discussing the concept of assessment in education, there are several terms that almost have the same meaning, namely measurement, assessment (assessment), and evaluation. For the reason, researcher will discuss three terms to equalize perception. The concept of assessment (Trianto, 2011:253), is a series of activities to obtain analyzing and interpreting data about the processes and learning outcomes of students which are done systematically and continuously in a sustainable manner, so that it becomes information which is meaningful in making decision.

In the curriculum 2013, the assessment is used refers to Permendikbud Number 66 of 2013 about education assessment standards. it has been mentioned that the assessment which is used is authentic assessment. According to Santrock (in Majid, 2017; 236), authentic 
assessment has been developed on the grounds that traditional assessment which is used all this time ignore the real world context and did not adequately describe the ability of students holistically. Authentic assessment is defined as an effort to evaluate student's knowledge and expertise in contexts the real world or real life. In this assessment students has been challenged to apply new information and skill to real situations to solve problems in order to achieve the goals set.

In authentic assessment, aspect of knowledge are not focus being tested only, but must be able to measure aspects of student's abilities as a whole including cognitive, psychomotor and affective

when the teacher makes an authentic assessment, there are three things that must be considered, they are: 1) Authenticity of the instruments used, 2) Authentic of what is measured, and 3) Authentication of aspects of student condition. In carrying out a good authentic assessment, the teacher must clearly understand what goals are being achieved, for example relating to aspects of ability, focus of assessment and the level of knowledge to be assessed. It was stated by Hargreaves in Majid (2017; 249), that authentic assessment is a form of assessment that reflects the actual learning outcomes, and can use a variety of ways or forms

Game. For the children, game has a very important role, the game is synonymous with the world of children, because children's daily activities are playing. According to John D Latuheru (in Yuliatun; 2014: 30), game is a form of activity where participants involved in it must act in accordance with established rules in order to achieve a certain goal

Children's mind are like sponges that are able to absorb information so amazing, but this process will only happen when children do it by playing. This happen because playing can make children happy, so it can improve the child's skills and development. (Suyadi; 2014: 183)

According to Jean Piaget, games can be used as a medium to improve children's cognitive development. This happens because sometimes the cognitive development of children can limit the way, they play so cognitive structures need to be trained. The same thing was stated by Vygotsky, the game is a very good setting for cognitive development. They are more interested in the symbolic and imaginary aspects of a game. (Hosnan; 2016: 177)

The game is a distraction for event that routinely take place in the classroom. game is a positive response to the learning process that serves as a form of reward for the sense of saturation due to being continuously in the learning atmosphere of watching. Through the game can make the learning environment become happy happy relaxed but still have a conducive learning atmosphere.

\section{Research Method}

The research design has been used by researcher in developing. this research instrument is the type of Borg and Gall research and development (R\&D) model. In the Borg and Gall model there are ten stages that researcher must go through to produce a product of valid development and reliability. So the researcher also carried out the ten stages in accordance with the ability of the author and adjusted to the needsin this research. To give explanation of the activities which has been carried out by researcher in accordance with the stages of developing the Borg and Gall model, it is described in the table below:

Table 1: Development activity table with Borg and Gall's model 


\begin{tabular}{|c|l|l|}
\hline \multicolumn{2}{|c|}{ Step Steps } & Description of Activities \\
\hline 1 & $\begin{array}{l}\text { Research and Information } \\
\text { Collecting. }\end{array}$ & $\begin{array}{l}\text { a. field research, researcherhas been done curriculum } \\
\text { analysis, analysis of learning conditions, student } \\
\text { analysis, and needs analysis. } \\
\text { b. Literature researchhas been done through a review of } \\
\text { books and sources relevant to the research to be } \\
\text { conducted }\end{array}$ \\
\hline 2 & Planning & $\begin{array}{l}\text { a. researcher has decided themes, object, analyze basic } \\
\text { competencies, } \\
\text { b. researcher has created an instrument assessment } \\
\text { framework design } \\
\text { c. researcher has determined the content, the parts of the } \\
\text { assessment instrument to be developed. }\end{array}$ \\
\hline 3 & $\begin{array}{l}\text { Develop Premilinary } \\
\text { Product }\end{array}$ & $\begin{array}{l}\text { The design that has been designed, compiled into an } \\
\text { initial product draft }\end{array}$ \\
\hline 4 & Preliminary Field Testing & The initial product draft has been validated by an expert \\
\hline 5 & Main Product Revision & Revision based on the results of expert validation \\
\hline 6 & Main Field Testing & $\begin{array}{l}\text { Trial small groups with the subject 10 Student of third } \\
\text { grade students at MI Ianatush Shibyan Bawu }\end{array}$ \\
\hline 7 & Operational Product Revision & Revision based on Small group trial \\
\hline 8 & Operational Field Testing & $\begin{array}{l}\text { Field trial has been conducted in tested on third grade MI } \\
\text { Ianatush Shibyan Jepara. }\end{array}$ \\
\hline 9 & Final Product Revision & Revision based on field trials \\
\hline 1 & $\begin{array}{l}\text { Dissemination } \\
\text { Implementation }\end{array}$ & $\begin{array}{l}\text { Distribution of products by attending seminars or } \\
\text { published in the form of journal }\end{array}$ \\
\hline
\end{tabular}

Trial subject in research and development of interactive game-based assessment instruments include: assessment experts, material experts, teachers and $3^{\text {rd }}$ grade students at MI Ianatush Shibyan Bawu Jepara. To test the level of product validity has developed, researcherhas used external method by asking for response and advice from experts who have master's qualificatios and manage the eyes of the college student according to their field of expertise. Further responses from users are teachers and students after using the product development. To test the validity of the data is done qualitatively by triangulation and discussion with friends or experts. validity test, reliability test, test item analysis, difficulty test analysis and distinguishing power analysis. While to test the effectiveness of the product development the researcher has used the t-test formula. In testing the product development data the researcher used computer-aided statistics, the SPSS Statistics.

\section{Research And Development Result}

As a basis for research and development, researcherhas done field research through direct observation and questionnaire distribution and conduct literature studies in an effort to find out the difficulties, measurements and product needs to be developed. In general, some problems So far in the assessment of learning outcomes is stressful for some students, learning in the classroom is still interesting and fun for students, the lack of teacher creativity in creating an interesting, innovative and fun evaluation instrument, the assessment instruments available are still not varied, most of them still use question sheets and multiple choice questions so it takes a long time to find out student learning outcomes and seems boring to students. And still the lack of facilities and infrastructure in primary schools that hinder the process of learning and assessment 
The design of the development product before being tested, researcher has been validated by the assessment experts and material experts. In general, the result of the validation responses by the assessment experts illustrated that the interactive game-based assessment instrument had a practical level of $81 \%$ and readability of $84 \%$. The total overall validation results of the assessment experts obtained a score of 82 with an average of 4.1 or $82 \%$

At the same time the researcher also has asked the material expert validator to provide feedback and input on product development. The result of the material expert responses illustrate that the assessment instrument has a 79\% conformity level, $80 \%$ completeness and $90 \%$ clarity. The results of the calculation of the total score of the responses of experts of the material is 140 with an average of 4 or by $80 \%$ of the maximum total score

The next stage, after the validation of the product expert has been revised based on the recommendations of the experts then the revised product has been tested on a small group. Product development has been tested on third grade MI Ianatush Shibyan Jepara. Then the researcher asked the teacher's response as a user to obtain information on the completeness, practicality and clarity of the product. The total total score was 86 with an average of 4.3 or $86 \%$ of the total overall score.

The next trial is a field trial. It has been done after revision based on suggestion in the small group. product trials has been carried out again, product development has been used by students and teacher three times the assessment activities in third grade MI I'anatus Shibyan Bawang, Jepara. Researcher has distributed questionnaires to teachers at the school. And the results of the questionnaire responses by the teacher obtained a data that the product developed has a completeness level of $85 \%$, has a practical level of $87 \%$ and a clarity of $90 \%$. The total number of overall scores was $87.3 \%$.

The researcher has done validity test through the response of the assessment expertand material expert in an effort to find out the level of conformity of the product developed with the theory and rules of assessment and the suitability of the ability of elementary school children. Researcher also has asked for responses from teachers as user of development product to obtain information related to the level of completeness, clarity and practicality of the product being developed

Furthermore, to test the validity of data items about the product development researcherhas done a validity test, reliability test, difficulty analysis and distinguishing power using computer-aided statistics, namely Anatesv4. The results obtained for the validity test with the biserial point correlation formula are that out of 30 questions 14 have a value of $\gamma \_$pbi $\geq 0.449,5$ have a value of $\gamma \_$pbi $\geq 0.349$ and 11 have a value of $p \_p b i<0.349$. And the reliability test data obtained $r=0.92$. Whereas for object analysis and the level of difficulty of 30 items obtained the results of 10 questions $p$ value $>0.75$, there are 5 questions with a value of $\mathrm{p} \leq 0.25$, and 14 questions with a value of $0.25<\mathrm{P} \leq 0.75$, while for a value of $\mathrm{D}>0.40$ there were 16 questions out of 30 questions tested, and for a value of $0.30<\mathrm{D} \leq 0.40$ there were 4 items, and a value of $P$ soal 0.20 there were 10 questions.

The final analysis hasbeen done by researcher in an effort to test the effectiveness of the product being developed. The data has beengottenthen analyzed using computer-aided statistics, namely SPSS Statistics 21 with the $t$-Test formula. The result has been obtained for the effectiveness test is the $t$ value of 5.32 is greater than $t$ table 1.721 with a significant level of $5 \%$.

\section{Dissemination of Research Result}


Expert Validity Analysis: Researcher has validated product development involving experts including assessment experts and material experts to determine predictions of content validity from development products. As revealed by Salkind (2013: 66), if the criterion is talking place in the future, we talk about predictive validity. The results obtained from expert validity on a scale of 1 to 5 , obtained a total of an overall score of 82 with an average of 4.1 or $82 \%$ of the total for expert validity, while the results of the material expert validity obtained an overall score of 140 with an average - average 4 or $80 \%$. Referring to the validity level table of Widoyoko $(2018 ; 123)$, the interactive game-based thematic assessment instrument is declared feasible to use, because with an average score of 4 and 4.1 , the development product is in the good category to be used because it has a value of $3,4<\mathrm{X} \leq 4,2$.

Targeting assessment on product development, researcher has referred to core competencies and basic competencies in the 2013 curriculum that cover all cognitive (KI-3), psychomotor (KI-4) and affective (KI-1 and KI-2) domains. As expressed by Pierangelo and Guiliani, 2012; 55), A good representation of content will always include several items for each domain, level, and skill being measured.

Furthermore, researcher has also asked for responses from teacher who has acted as product user, the results of the validation by teacher who are more focused on knowing the quality of product usage guidelines and assessment guidelines of product development. The overall total score obtained was 86 with an average of 4.3 or $86 \%$ of the total overall score. Then the assessment instruments are declared very easy to use and read. As Akbar's opinion (2013: 2), that a product developed has a level of completeness and convenience between $75.01 \%-100 \%$ in the very good category, even with an average of $75.01 \%-100 \%$ development products can be directly used without making revisions .

Item Analysis Problem. item test trial is very important, as has been revealed by Amirono and Daryanto (2016: 177), analysis of the results of the test is carried out as an effort to obtain instruments that are categorized as good. From the results of the analysis of computer-aided items namely Anates, the results obtained for the validity test of 30 questions there were 14 had a value of $\gamma \_p b i \geq 0.449,5$ had a value of $\gamma \_p b i \geq 0.349$ and 11 had a value of $\mathrm{p} \_$pbi $<0.349$. It can be concluded that 14 items with very significant criteria, 5 questions with significant criteria and 11 questions with less significant criteria

Based on the reliability test results has been obtained $r$ value of 0.92 . So the test question instrument has been declared reliable. As the opinion of Amirono and Daryanto (2016: 196), that a reliable instrument is an instrument that has a minimum reliability coefficient of 0.70 , preferably an instrument reliability coefficient of 0.80 or more

The results of the test items by referring to the difficulty level table of Amirono and Daryanto (2016: 180), result has been obtained from 30 items obtained the results of 10 questions $p$ value $>0.75$ means that the category is easy, there are 5 questions with $p$ value 0.25 in the category difficult, and 14 questions with a value of $0.25<\mathrm{P} \leq 0.75$ in the medium category. Then the instrument was stated to be quite good, as expressed Amirono and Daryanto (2016: 180), that a good test instrument has items with proportional difficulty levels. This means that the instrument is not dominated by items that are relatively easy

Eferring to the Amirono and Daryanto different power index tables $(2016 ; 181)$, the results obtained differed power values $>0.40$, there were 16 questions that had very good categories from 30 questions tested, and for values of $0.30<\mathrm{D} \leq 0.40$ there 4 items in the category are sufficient, and the value of $\mathrm{P} \leq 0.20$ there are 10 questions in the poor category.

Level of Effectiveness Analysis. The product has been tested to determine its effectiveness using computer-aided statistics, namely through the SPSS statistical application 19 using the paired sample $t$ test formula, and the results of $t$ count are 5.32, greater than $t$ 
table 1.721 with a significant level of $5 \%$. This proves that there is a significant relationship between products developed with student learning outcomes.

\section{Conclusion}

Development of thematic assessment based on interactive game in elementary school has been developed using the Borg and Gall stages which have 10 stages that are specifications in order to produce good products and in accordance with what is expected. The product developed has been declared valid in both categories by the appraisal expert and material expert so that the product could be used and mild revisions has been made. The product usage and assessment guidelines are also stated to be very easy to be used and read so that they can be used without making revisions.

To obtain a good instrument, the product is also tested item analysis through validity test, reliability test and item analysis to see the consistency and quality of instrument results. From the test results the product is declared valid, reliable and good so it can be used. The product of the development results was also declared effective to create a learning assessment that has been focused but fun and able to improve the learning outcomes of students.

The product has been developed only limited to the theme 1 sub-themes 1, 2 and 3 in third grade and only contains 3 course contents namely civics, Mathematics and Indonesian. The product is also limited to the scope and scope of the material contained in the teacher and student books. Future assessment is expected to be able to develop all themes in third grade elementary school and have a depth and breadth of the material beyond the scope of the material in the 2013 teacher and student curriculum book.

\section{References}

[1] Abdul Majid. Pembelajaran Tematik Terpadu. Bandung:Remaja Rosdakarya.(2017)

[2]Amirono, dan Daryanto.Evaluasi dan Penilaian Pembelajaran Kurikulum 2013, Yogyakarta: Gava Media(2016)

[3]Hamzah B. Uno, dan Satna Koni. Assesment Pembelajaran. Jakarta: Bumi Aksara.(2010)

[4]Harun Rasyid, dan Mansur. Penelitian Hasil Belajar. Bandung: Wacana Prima.(2009)

[5]Hosnan, Psikologi Perkembangan Peserta Didik. Bogor: Ghalia Indonesia.(2016)

[6]N.J Salkind, Test \& Measurement for People Who Think They Hate Test \& Measurement (United States of America: Sage Publication, Icn,2013)

[7]R. Peraangelo, \& G. A. Giuliani, Assesment in Special Education, A Practical Approach (United States of America: Pearson Education, Icn,2012)

[8]S. Akbar, 2013, Instrument Perangkat Pembelajaran,Bandung; Remaja Rosdakarya.(2013)

[9]S. Eko Saputro Widoyoko, Teknik Penyusunan Instrumen Penelitian, Yogyakarta: Pustaka Pelajar.(2018)

[10]Sakbana Rendra Kusuma, Penilaian Autentik Berbasis Permainan Di Sekolah Dasar (Studi pada Kelas V Sekolah Dsar pada Kurikulum 2013) Jurnal Inventa. 7(2). 24-32.(2018)

[11]Selamet Suyanto, Dasar-Dasar Pendidikan Anak Usia Dini, Yogyakarta: Hikayat Publishing.(2015)

[12]Sugiyono. Metode Penelitian dan Pengembangan Research and Development. Bandung: Alfabeta.(2017)

[13]Suyadi.Teori Pembelajaran Anak Usia Dini Dalam Kajian Neorosains. Bandung: Remaja Rosdakarya.(2014)

[14]Trianto.Desain Pengembangan Pembelajaran Tematik bagi Anak Usia Dini TK/RA \& Anak Usia Kelas Awal SD/MI. Jakarta: Kencana Prenada Media Group.(2011) 
[15]Tutik Yulianto, Pengembangan Instrumen Penilaian Berbasis Media Permainan Jumanji untuk Mengukur Penguasaan Materi Fisika dan Pencapaian Minat Belajar Peserta Didik Sma. Skripsi tidak diterbitkan. Yogyakarta :Universitas Negeri Yogyakarta.(2017) 